Reprod. Nutr. Dévelop., 1988, 28 (2 B), 423-429.

\title{
Melatonin and light treatment of ewes for autumn lambing
}

\author{
H. WILLIAMS, Sandra WARD \\ with the technical assistance of Kim CAIRNS and Jackie THOMSON
}

Department of Veterinary Medicine and Animal Husbandry, The Roval Veterinary College, Potters Bar, Herts. EN6 1NB, England.

\begin{abstract}
Summary. Forty spring lambing adult, and 24 unbred yearling, Suffolk crossbred ewes were allocated to 3 groups. Group I and II were maintained on 18L : $6 \mathrm{D}$ and Group III on Local light $\left(51^{\circ} 42^{\prime} \mathrm{N}\right)$ during 24 Feb - 13 April. During 13 April - 11 July Group I changed to 9L : 15D and Groups II and III were group fed a diet containing melatonin and providing $3 \mathrm{mg} /$ ewe at 16.00 hrs daily. A further 20 adult ewes, Group IV and $V$ were maintained on Local light during 24 Feb - 13 April ; Group IV was transferred to 9L : 15D and Group V remained on Local light during 13 April - 11 July. The ewes were exposed to vasectomised rams from the time of weaning on 3 June. All ewes were housed until 11 July and then remained at pasture thereafter.

The performance of the yearling ewes was as follows - \% Keel-marked during 11-28 follows : Group I - 90.0 ; Group II - 100.0 : Group III 92.3 ; Group IV - 50.0 ; Group V -10.0. There were no significant differences between Groups I, II and III. The following percentage of adult ewes lambed during $3-23$ December $-66.7 ; 85.7 ; 69.2 ; 20.0$ and 0.0 for Groups I - V respectively. Groups I, II and III were significantly higher than Group V.

The performance of the yearling ewes was as follows - \% keel-marked during 11-28 July : Group I - 100.0; Group II - 66.7; Group III - 22.2. The following percentage of yearling ewes lambed during 3-23 December - 50.0; 44.4 and 11.1 for Group I - III respectively.
\end{abstract}

An assessment of these data in relation to autumn lambing is presented in the paper.

\section{Introduction.}

Recent changes in the EC Guide Price for fat lambs coupled with new developments in sheep husbandry and grazing management have increased interest in autumn lambing and earlier spring lambing. The natural capacity to lamb at these times is restricted to few genotypes, some of which are not regarded as very prolific. Efficient performance in most lowland systems of UK sheep production demands compact lambing and a high lambing percentage. These objectives can only be achieved when all ewes are cyclic during a restricted period of mating and when fertility and ovulation rate are high.

During the last 35 years the treatments available for out-of-season breeding have not made a significant impact on British systems of lamb production. In the 
case of progestagen - PMSG treatment - it has been largely due to an unacceptably low level of fertility following treatment during deep anoestrum (Gordon, 1983). Photostimulation on the other hand results in a high level of ferility and is the only treatment which confers the advantages of oestrous cyclicity (Williams, 1977). The need for a controlled environment house to provide a long night during April-June has curtailed its use partly due to the cost of providing such a facility and partly due to the disruption of traditional management during the spring grazing period. Nevertheless photostimulation has been effectively practised over several years in some large flocks.

In assessing the role of melatonin as a replacement or supplement to photostimulation for autumn lambing it is pertinent to comment briefly on the type of, and response to, light treatments which have involved the Dec-June period.

A variety of light treatments derived from an empirical approach to photoperiodicity have been effective in initiating a breeding season in June (Williams, 1970). The majority of these treatments have simply advanced the normal increasing and decreasing phase of the photoperiod of their locality or exaggerated it. Irrespective of the amplitude or timing of treatments the responses of the breeds involved have been remarkably uniform with the majority successfully initiating the onset of a breeding season in June. One would expect the same response in British ewes exported during the winter to a comparable latitude in the southern hemisphere. Ewes subjected to a simulated equatorial photoperiod 13L : 11D from January show an earlier onset to the subsequent breeding season but with clear breed differences in the proportion of ewes exhibiting oestrus and also in the duration of the breeding season (Williams, 1974).

Attempts to eliminate the need for a priming period of long days (18L : 6D) by subjecting ewes to an abrupt change to short days (10L : 14D) on 1 March, 1 April and 1 May showed variable results. The reaction intervals of the 3 treatments were $186.5 \pm 3.8,127.3 \pm 3.5$, and $106.2 \pm 2.3$ days respectively. In the case of those treated from 1 March, 4 of 10 ewes were still in anoestrum when the investigation terminated at the end of October. Although there was an uniform and early response in the other 2 groups it did not provide the opportunity for autumn lambing (Williams, unpublished data).

The role of melatonin in the photoperiodism of sheep was clearly established in the early 80s (Nett and Niswender, 1982 ; Arendt et al., 1983 ; Bittman et al., 1983). These studies initiated a reappraisal of photostimulation as a treatment for out-of-season breeding for it was now possible to consider melatonin treatment, due to its availability (Sigma), as an alternative to the costly long night phase. The initial investigation at the RVC assessed the efficacy of group feeding ewes with a diet providing approximately $3 \mathrm{mg}$ per ewe at $16.00 \mathrm{hrs}$ daily during late anoestrum. The advanced breeding season was normal in terms of duration of first oestrous cycle, ovulation rate and embryo survival (Williams, 1984). In 1984 melatonin treatment ( $4 \mathrm{mg} / \mathrm{ewe}$ at $16.00 \mathrm{hrs}$ ) was adopted for spring lambing ewes during 5 April - 2 July. The ewes had been previously exposed to $18 \mathrm{~L}: 6 \mathrm{D}$ from 7 Feb. The onset of the breeding season and fertility of the ewes did not 
differ significantly from the conventional $18 \mathrm{~L}: 6 \mathrm{D} ; 9 \mathrm{~L}: 15 \mathrm{D}$ treatment. Ninetytwo per cent of the ewes lambed in late Nov/early Dec. (Williams, 1985). That initial investigation has been repeated to include two age groups, adult and yearling Suffolk crossbreds and expanded to include the use of melatonin during spring/early summer without a priming period of supplementary light. The results are presented below.

\section{Materials and methods.}

In February 1986, 60 adult and 24 yearling Suffolk crossbred ewes were allocated to treatments shown in Table 1.

TABLE 1

Animals and treatments.

\begin{tabular}{cccccc}
\hline & \multicolumn{2}{c}{ Treatment and period } & \multicolumn{2}{c}{$N^{\circ}$ of ewes } \\
\cline { 2 - 3 } \cline { 5 - 5 } Group & 24 Feb -13 April & 13 April -11 July & Adult & Yearling \\
\hline II & $18 \mathrm{~L}: 6 \mathrm{D}$ & $9 \mathrm{~L}: 15 \mathrm{D}$ & 10 & 6 \\
III & $18 \mathrm{~L}: 6 \mathrm{D}$ & Melatonin (1) & 15 & 9 \\
IV & Local (2) light & Melatonin & 15 & 9 \\
V & Local light & $9 \mathrm{~L}: 15 \mathrm{D}$ & 10 & - \\
\hline
\end{tabular}

(1) Melatonin (Sigma) - Group fed pelleted diet $(100 \mathrm{~g} / \mathrm{ewe}$ ) providing approximately $3 \mathrm{mg} / \mathrm{ewe}$ at 16.00 hrs daily.

(2) $51^{\circ} 42^{\prime} \mathrm{N}$; on April 13, approx. 15L : 9D.

Fifty five of the adult ewes lambed in early April 1986 (7 April \pm 1.63 ); the mean litter size was $1.98 \pm 0.21$. The yearling ewes had remained unbred during the previous autumn. The ewes were housed throughout the treatment periods and were fed on dried grass cubes, proprietary concentrate and supplements according to recommended rates. The ewes were shorn on 12 May and all lambs were early weaned on 3 June. The ewes were exposed to vasectomised rams during 5 June - 11 July and 28 July - 11 Aug. and to entire rams during 11 28 July and 11 Aug. - 15 Nov.

\section{Results and discussion.}

Adults: Autumn lambing. - The percentage of ewes keel marked by vasectomised rams during 5 June - 11 July was 40.0, 60.0, 42.9, 20.0 and 0.0 for Groups I - V respectively, with only the difference between Group II and Group V $(0.0 \%)$ attaining statistical significance $(p<0.01)$. The distribution of keel marking did not indicate a response to the entry of the ram on 5 June. 
The incidence of keel marking by entire rams during 11-28 July is presented in Table 2 together with the percentage of ewes lambing during 3-23 December.

TABLE 2

Reproductive performance of adult ewes.

$i$ - Autumn lambing.

\begin{tabular}{lccccc}
\hline \multicolumn{1}{c}{ Group } & $\mathrm{I}$ & $\mathrm{II}$ & $\mathrm{II}$ & $\mathrm{IV}$ & $\mathrm{V}$ \\
\hline $\begin{array}{l}\text { \% keel marked ; } \\
\text { entire rams ; }\end{array}$ & $90.0^{\mathrm{a}}$ & $100.0^{\mathrm{bc}}$ & $92.3^{\mathrm{d}}$ & $50.0^{\mathrm{b}}$ & $10.0^{\mathrm{acd}}$ \\
$\begin{array}{l}11-28 \text { July } \\
\text { \% lambed }\end{array}$ & & & & & \\
3-23 December & $66.7^{\mathrm{e}}$ & $85.7^{\mathrm{fg}}$ & $69.2^{\mathrm{h}}$ & $20.0^{\mathrm{f}}$ & $0.0^{\mathrm{egh}}$ \\
Litter size & 1.50 & 1.42 & 1.44 & 1.50 & - \\
\hline
\end{tabular}

Values with similar superscript are significantly different.

b, $p<0.05 ; a, e, f, h, p<0.01 ; c, d, g, p<0.001$.

It is evident that a high incidence of keel marking occurred in Groups I - III. The majority of ewes in these 3 groups, $66.7,85.7$ and $75.0 \%$, conceived during this first service and lambed during 3-23 December. There were no significant differences between the values shown for Groups I - III for keel marking or lambing. The performance of Group IV was lower than Groups I - III largely due to persistent anoestrum in half the ewes and a low conception rate in served ewes. In Group V only one ewe was keel marked but failed to lamb.

Litter size in all groups was considerably lower for the December lambing compared with the previous lambing in the spring. This was mainly the effect of lactation on the body condition of the ewes and the lack of opportunity to regain weight and condition during the post-weaning phase in June. The mean liveweight of the adult ewes at weaning and at the end of treatment was $59.3 \pm$ $3.84 \mathrm{~kg}$ and $59.4 \pm 3.76 \mathrm{~kg}$ respectively. There were no significant differences between treatment groups. The average liveweight during the pre-mating period was approximately $10 \mathrm{~kg}$ lower than the target weight for this breed type at mating.

Adults : Winter lambing. - The subsequent lambing performance of those which failed to lamb in December is presented in Table 3.

It can be seen that the majority lambed during January and thus conceived early in the second mating period (11 Aug - 15 Nov). Lambings in Groups III were protracted and three ewes were barren; two of the barren ewes had been recorded pregnant during scanning in October, the third ewe had only been keel marked once by a vasectomised ram.

Yearlings: Autumn lambing. - The percentage of yearling ewes keel marked by vasectomised rams during 5 June - 11 July was $67.0,22.2$ and 44.4 in 
TABLE 3

Reproductive performance of adult ewes. ii - Winter lambing.

\begin{tabular}{rlcccc}
\hline Group & I & II & III & IV & V \\
\hline $\mathrm{N}^{\circ}$ of ewes lambing during : & 1 & 1 & 2 & 3 & 7 \\
Jan & - & - & 1 & 1 & 3 \\
Meb & - & 1 & 2 & - & - \\
March & 2 & - & 3 & - & - \\
Larren ewes & 1 & 1 & - & 2 & - \\
\hline
\end{tabular}

(1) Unrelated to treatment.

Groups I - III respectively. Their reproductive performance following exposure to entire rams is shown in Table 4.

All yearlings in Group I were keel marked by entire rams compared with $22.2 \%$ in Group III ( $p<0.05$ ). However, due to low conception rate, only $50 \%$ of Group I lambed in December. The proportion lambing in the other two groups was also lower than for keel marking.

The yearling ewes weighed $50.8 \pm 1.43 \mathrm{~kg}$ at the end of the treatment periods and had gained an average of $12.0 \mathrm{~kg}$ during treatment.

Yearlings: Winter lambing. - The subsequent lambing performance of yearling ewes which failed to lamb in December is shown in Table 5.

TABLE 4

Reproductive performance of yearling ewes.

$i$ - Autumn lambing.

\begin{tabular}{lccc}
\hline \multicolumn{1}{c}{ Group } & \multicolumn{1}{c}{ I } & II & III \\
\hline \% keel marked ; entire rams ; & $100.0^{\mathrm{a}}$ & 66.7 & $22.2^{\mathrm{a}}$ \\
11-28 July & 50.0 & 44.4 & 11.1 \\
\% lambed 3-23 December & 1.0 & 1.0 & 1.0 \\
Litter size & & \\
\hline
\end{tabular}

a, $\mathrm{p}<0.05$

TABLE 5

Reproductive performance of yearling ewes. ï - Winter lambing.

\begin{tabular}{|c|c|c|c|}
\hline Group & 1 & II & III \\
\hline \multicolumn{4}{|l|}{$N^{\circ}$ of ewes lambing during: } \\
\hline Janv & - & - & - \\
\hline Feb & - & - & 2 \\
\hline March & 1 & 2 & 2 \\
\hline April & - & - & 2 \\
\hline Barren ewes & 2 & 3 & 2 \\
\hline
\end{tabular}


No lambings occurred during January and February in Groups I and II. The majority of yearlings lambed in late February and March ; the lambings were more protracted in Group III. The distribution of lambings clearly indicates that effective matings took place in Sept/Oct. Most of the animals had remained in anoestrum during the earlier months. Barreness occurred in all groups. One ewe in each of Groups I and II had been diagnosed pregnant in October. The remaining barreners had shown only sporadic activity during June-September.

\section{Conclusions.}

In terms of flock management only the treatments applied to Groups II and III may be readily adopted for autumn lambing. The protracted lambings in Group III indicate that further investigation is required to improve the acceptability of that form of treatment.

The data relating to Group II demonstrate that the daily feeding of a diet supplemented with melatonin at $16.00 \mathrm{hrs}$ is an effective treatment for providing the opportunity for autumn lambing in adult Suffolk crossbred ewes. The data also confirm similar findings in an earlier investigation at The Royal Veterinary College (Williams, 1985). The priming period of supplementary light applied to Group II does not pose a management problem for an increasing number of lowland flocks which house breeding ewes, for other reasons, during the autumn/winter. However the widespread commercial appeal of this new approach to out-of-season breeding will greatly depend on the development of alternative methods of melatonin administration. It is of interest that early breeding was achieved in this investigation by feeding melatonin only before sunset. The fact that sunrise occurred earlier each day during 14 April - 21 June suggests that the duration of high levels of plasma melatonin is not critical at this time of the year.

The high level of fertility in adult ewes in 1984 and 1986 was not matched by a high level of fecundity. This was largely due to the lateness of the lambings and failure to restore body condition prior to mating. This breed type has the capacity to lamb in January/February (see Group V); flocks lambing this early and particularly where early weaning is practised, have ample opportunity to restore body condition through grazing high quality pastures during the spring/early summer.

It is acknowledged that the yearling ewes were still in an active phase of their growth and development during the treatment periods. Since they were only $70 \%$ of their adult weight at that time their performance cannot be expected to be as high as the adult ewes. Nevertheless, their performance should be higher than that expected from ewe lambs in their first autumn. The poor performance of the small number of yearling ewes in this investigation requires further investigation. In terms of ease of management, and availability of stock, this particular age group is ideally suited to initiate autumn lambing in any flock. 
Acknowledgements. - The investigation was partly funded by MAFF Research Grant CSA 1068.

\section{Résumé. Mélatonine et traitement lumineux pour obtenir l'agnelage d'automne.}

Des brebis croisées Suffolk (40 adultes ayant agnelé au printemps et 24 antenaises nulliparts) ont été réparties en 3 groupes.

Les groupes I et II étaient maintenus sous $18 \mathrm{~L}: 6 \mathrm{D}$ et le groupe III soumis à l'éclairement naturel $\left(51^{\circ} 42^{\prime} \mathrm{N}\right)$ du 24 février au 13 avril. Du 13 avril au 11 juillet, le groupe I est passé sous $9 \mathrm{~L}: 15 \mathrm{D}$ et les groupes II et III ont reçu une alimentation contenant de la mélatonine apportant chaque jour $3 \mathrm{mg} / \mathrm{brebis}$ à $16 \mathrm{~h}$. Vingt autres brebis adultes, groupes IV et $V$, étaient maintenues sous éclairement naturel du 24 février au 13 avril. Le groupe IV était transféré sous $9 \mathrm{~L}$ : $15 \mathrm{D}$ et le groupe $\mathrm{V}$ est resté sous éclairement naturel du 13 avril au 11 juillet. Les brebis étaient en présence de béliers vasectomisés depuis le moment du sevrage jusqu'au 3 juin. Toutes les brebis ont été en bergerie jusqu'au 11 juillet et remises ensuite au pâturage. Le pourcentage des brebis adultes marquées par des béliers entiers entre le 11 et le 28 juillet se répartit de la façon suivante : Groupe I : 90.0 - Groupe II : 100.0 - Groupe III : 92.3 - Groupe IV : 50.0 - Groupe V : 10.0. II n'y a pas de différence significative entre les Groupes I, II et III. Le pourcentage des brebis adultes mettant bas entre le 3 et le 23 décembre était : $66.7 ; 85.7 ; 69.2 ; 20.0$ et 0.0 pour les Groupes de \& à $\vee$ respectivement. Les Groupes I, II et III étaient significativement plus élevés que le Groupe V.

Les performances des brebis antenaises se répartissent ainsi : pourcentage de brebis marquées entre le 11 et le 28 juillet : Groupe I : 100.0 - Groupe II : 66.7 - Groupe III : 22.2 . Le pourcentage des antenaises agnelant entre le 3 et le 23 décembre : $50.0 ; 44.4$ et 11.1 pour les Groupes I à III respectivement.

La discussion de ces résultats par rapport à ceux des mises-bas d'automne est présentée dans cet article.

\section{References}

ARENDT J., SYMONS A. M., LAUD C. A., PRYDE S. J., 1983. Melatonin can induce early onset of the breeding season in ewes. J. Endocr., 97, 395-400.

BITTMAN E. L., DEMPSEY J., KARSCH F. J., 1983. Pineal melatonin secretion drives the reproductive response to daylength in the ewe. Endocrinology, 113, 2276-2283.

GORDON I., 1983. Controlled breeding in farm animals. Pergamon Press, Oxford.

NETT T. M., NISWENDER G. D., 1982. Influence of exogenous melatonin on seasonality of reproduction in sheep. Theriogenology, 17, 645-652.

WILLIAMS H. LL., 1970. The photoperiodicity of British ewes. Span, 13, 1-3.

WILLIAMS H. LL., 1974. The reproductive performance of two British breeds of sheep in contrasting photoperiodic environments. J. agric. Sci. Camb., 82, 377-381.

WILLIAMS H. LL., 1977. Environmental control of oestrus with particular attention to alterations of daylength. Proc. 28th Ann., Meeting, E.A.A.P., Brussels, Belgium. M-SG/5.04/1-6.

WIILLIAMS H. LL., 1984. The effect of feeding melatonin during late summer on the onset of the breeding season of sheep. Br. vet. J., 140, 407-408.

WILLIAMS H. LL., 1985. The use of melatonin to initiate breeding activity in photoperiodic breeds of sheep. Proc. 36th Ann. Meeting, E.A.A.P., Halkidiki, Greece, 2, 240-241 (Abstr.). 